\title{
The need for an effective and integrated environmental policy: lessons from Hungary
}

\author{
Viktor Varjú \\ MTA KRTK Institute for Regional Studies \\ H-7601 Pécs, Pf. 199, Hungary \\ varju@rkk.hu
}

\begin{abstract}
Subsidies of the EU funds resulted in major projects and plans. In order to prevent natural disasters, the European Community - among others - introduced the Strategic Environmental Assessment (SEA). With the SEA the environmental aspects prevailed in an earlier phase of the planning process. The SEA is mostly new means in the new Member States, hence the planners and stakeholders had to learn to incorporate it into their practice. On the other hand, the existing institutional structure of a country influences the planning decision making processes. This paper examines the introduction of and difficulties associated with the SEA in Hungary while focusing on institutional settings and integration elements.
\end{abstract}

Keywords: environmental policy integration (EPI), strategic environmental assessment (SEA), regional development, planning, development policy.

\section{Introduction}

Since the 1980's the redistribution system of European Community (EC) has resulted in the implementation of major projects and plans. The second largest share of the EU budget, the European structural funds, became one of the most important policies in the EU (Dąbrowski 2008). The growth of the number of investments is inevitably followed by the increasing land use, emissions and contamination of the environment.

Lafferty and Hovden (2003) argued that, as the concept of 'sustainable development' in the 1980s and 1990s emerged as a central element, the environmental sector alone would not be able to secure environmental objectives, therefore, each sector would have to take on board environmental policy objectives (Lafferty \& Hovden 2003, p.1).

With the strengthening and far-reaching effect of the environmental policy the idea of Environmental Policy Integration (EPI) came to the front in the last decades. The fifth EU Environmental Action Programme urged the assessment of the environmental impact in policy planning, consideration of environmental costs and benefits, monitoring of environmental effects, co-operation with environmental authorities and public availability of environmental information (Lenschow 1997, 1999).

After the systemic change the Central and Eastern European Countries (CEEC) had twofold tasks. They had to transfer/turn their system into a western type market based regime and they also 
would not like to miss the opportunity of being a member of a rich and "borderless" community. When during the preparation for the EU accession it turned out that strategic planning would be in great demand, the rehabilitation of planning activities had started. Concurrently the Europeanisation process plays a crucial role in the transformation of the CEEC and Hungarian governance structures. The adaptation processes are significantly dependent on the learning capacity of the pre-existing institutional "infrastructure". (Pálné et al. 2004). Evidently, the attributes of public planning are influenced by these institutional settings.

The Strategic Environmental Assessment (SEA) is a new tool which helps integrate the Environmental Policy Integration (EPI) into regional development policy. The SEA appears in a different form in different national organisations' (e.g. EU) development policy. There are countries where environmental assessment has longer term experience (e.g. USA, UK, France, the Netherlands) and there are countries (e.g. Hungary, Slovakia) where the SEA implementation has just started.

In the 2000s there were a number of SEA preparations related to different sectoral strategies and the literature also dealt with peculiarities of the SEA (cf. Varjú 2008). In most CEEC countries the SEA debuted institutionalised for the first time in the programme preparation for the planning period of 2007-13. This paper seeks out how the different determinants, factors, "infrastructures"/ /institutional settings affect the effectiveness of EPI.

\section{The SEA and the EPI}

As Degórski (2010) suggests, in order to avoid unpredictability in regional development trajectories, the consideration of the qualities of the natural environment is very important factor (Degórski 2010). Strategic environmental assessment is a process that aims to integrate environmental and sustainability considerations in the decision-making process. It has the potential to make the world a greener and more liveable place (Therivel 2004, p. 3).

Although the tool of Environmental Assessment appeared in the late 1960s in the USA and the 1970s in European countries (e.g. France, the Netherlands) (Szilvácsku 2003), in Europe the common institutionalisation has been made in the 2000s.

In order to assess the impact of major investments on the natural environment, the European Community introduced the Environmental Impact Assessment (EIA) (85/337/EC). As the need for evaluation of human actions increased, during the reform of Structural Funds the ex-ante and midterm evaluation was drawn up and became obligatory in programming and planning. Then between 1994 and 1999 the concept of the ex-ante and ex-post evaluation in the Member States' programs was defined (Czira et al. 2004). The development of the ex-ante evaluation and the crescendo of environmental policy (e.g. the Cardiff process (Feldmann \& Vanderhaegen 2001) brought forth the need for a separate evaluation tool for integrating environmental interests more deeply. The goal of this initiative was also to integrate environmental policy in an earlier phase of the programmingplanning procedure. Extending the Assessment and using the practice of some developed countries, the EU introduced the Strategic Environmental Assessment (SEA) in its "Directive 2001/42/EC of the European Parliament and the Council on the assessment of the effects of certain plans and programs on the environment", which should have been implemented by the Member States by July 2004 (although several countries have not enacted the SEA (Strategic Environmental Assessment) in their legislation by the specified time). 
Although the goal is to integrate environmental policy and sustainability into planning and programming, SEA Directive (2001/42/EC) specifies neither any precise environmental limits nor methodology. It sets procedural requirements, preparation of an environmental report which describes the significant environmental impacts of the proposed plan or programme (Therivel et al. 2009). Hence the SEA application gives planners and SEA conductors plenty of rope to perform a more or less proper SEA process resulting in really or poorly sustainable plans and programmes.

The SEA refers to the environmental assessment of policies, plans and programmes. The importance of SEA - in contrast to the environmental impact assessment (EIA) - consists in that the SEA steps in the planning/decision-making process earlier (see Fig. 1.), therefore, the major problems can be revealed prior to the investments. Secondly, the SEA deals with cumulative and synergic impacts of multiple projects, strategic plans and programmes. The aim of SEA is to provide decision makers and affected stakeholders with timely and relevant information on the potential environmental impacts of a plan in order to modify it and make it environmentally sounder (Wood 2005).

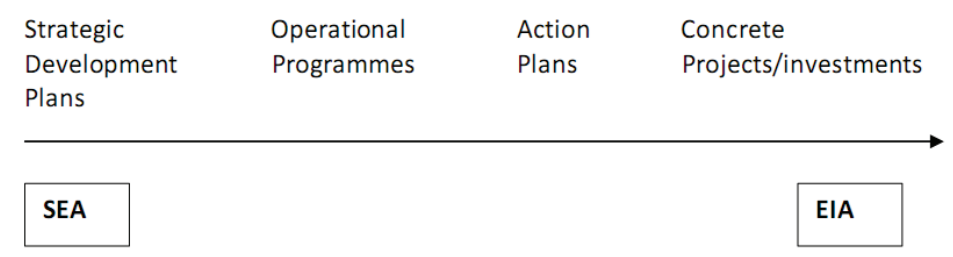

Figure 1. The place of the EIA and SEA in the planning/decision making procedure

Determining whether an environmental policy initiative and integration is 'effective' is problematic. The reason is that there are different types of effectiveness to consider (Theophilou et al. 2010). Sadler (1996) distinguishes three types of effectiveness:

"Procedural - Does the environmental assessment (EA) process conform to established provisions and principles?

Substantive - Does the EA process achieve the objectives set, e.g. support well-informed decision-making and result in environmental protection?

Transactive - Does the EA process deliver these outcome(s) at the lowest cost in the minimum time possible, i.e. is it effective and efficient?" (Sadler 1996, p. 39)

One of the most important elements of the SEA process is how it is integrated into the planning process. Although the form of integration does not determine whether a planning process - using SEA - results in a real sustainable plan/programme or not, the profoundness of the integration may indicate the sustainability level of a plan and refer to the substantive effectiveness of the assessment.

Evidently, the complexity of the environmental system should be reflected in the substantive planning approach. Besides the latter, the procedural planning issues need to be considered (Partidário \& Voogd 2004, p. 287).

In order to consider substantive integration in planning by means of SEA, Partidário \& Voogd (2004) defined four types of integration. In full integration, "environmental factors and concerns are an intrinsic element in the formulation of actions amenable to strategic decisions". In Environmental shape assessment about the importance and magnitude of potential positive and negative effects on the environment is missing. In the Concurrent assessment and 'Staple' integration iterativity is totally missing. "Full integration is the most desirable means by which the sustainable development can be achieved" (Partidário \& Voogd 2004, pp. 291-292). 
Simultaneously, the key aspect of addressing sustainability consists in a problem of coordination/integration of action at different levels of governance (Atkinson \& Klausen, 2011). Basic modes of governance include hierarchy, markets and networks. 'Hierarchical coordination involves the centralised, formally organised exercise of top-down authority, whereas markets provide coordination in the form of mutual self-adjustment among autonomous actors by way of the price mechanism. Network governance modes are distinguished from the other two modes in that they allow for direct co-ordination among operationally autonomous, yet interdependent actors inside self-adjusting and often informal networks' (Atkinson \& Klausen 2011, pp. 233-234; Heinelt et al. 2006).

Public planning has bureaucratic and political practice as well. Bureaucratic peculiarity is articulated via the institutional structure of a society, whilst political practice is exercised by the politically active actors (Partidário \& Voogd 2004, p. 287). Traditional political culture, newly emerged political practice (such the Europeanisation) and bureaucratic institutional structure of a country have significant impact on the manifestation of public planning process and decision-making. Hence, each element - such an integrated process - of a planning procedure is influenced by the mentioned peculiarities. Therefore, the integration attributes of environmental policy depend on the complex institutional settings of a country.

In this paper I argue that the bureaucratic culture and the elements of the institutional settings of a country determine the "level" and other substantive and procedural peculiarities of the environmental policy integration.

\section{Methods and materials}

Research had been started with processing of secondary sources. Regarding the EPI and knowledge sociological examination semi-structural and deep interviews were made. Also land use plans and regional development documents with content analyses were reviewed. Having regarded the application of strategic environmental assessment on different spatial levels in Hungary the National Development Agency's documents related to the planning period of 2007-2013 were also analysed.

Having established a position for the research in relation to the Hungarian frame, the recent paper was based on several researches. Under the umbrella of the $6^{\text {th }}$ research framework program called GFORS (Governance for Sustainability), we analysed the operational programs of the Second National Development Plan (2007-2013) of Hungary (National Strategic Reference Framework (NSRF) in the EU terminology), especially focusing on the South-Transdanubian Regional Operational Program as a case study. Secondly, the focus has been extended to the local level. The author tried to find out how the application of the new legislation helps make the local level "greener". In order to map the territorial level a questionnaire based research with document analysis was carried out by the author.

In the G-FORS research project, interviews with the actors were carried out and important documents (plans, minutes, websites etc., and altogether about 80 items) were analysed with regard to the legislation, planning and SEA making process. Almost all of the actors have been contacted in the issue of SEA, more than 20 interviews were carried out with the intent to adequately represent different types and levels of actors. On the other hand in the case study we could hardly rely on information provided by the media since there were scarcely any articles concerning this topic.

In the Analysis of the local level the focus was on the counties and settlements. The research examined whether the local decision-makers had enough information about the new tool and whether there were any difficulties in application. In this research the author sent out questionnaires to all the 
Hungarian settlements where an e-mail address was available (almost $80 \%$ of the 3150 Hungarian settlements). Thus, all the different types of settlements could be reached. The author received answers from more than 400 mayors/local governments (16\% of the sent questionnaires), however, small villages (fewer than 1000 inhabitants) were underrepresented, and large settlements (settlements over 10000 inhabitants) were overrepresented, therefore data have been weighted.

\section{Results}

\section{Institutional framework}

A case cannot be understood without the specific physical, social, cultural environment (attributes of community) and the general model of governance, the evolution and characterisation of institutional arrangements (Ostrom 2005). Knowledge is also a crucial element of this system. Different knowledge types have different impact on economic as well as regional development (Florjańczyk et al. 2012). It is essential to analyse how different governance arrangements in different institutional structures (countries) may be enabled to generate, transfer different knowledge forms (e.g., institutional, expert, steering, milieu etc.) and accompanied by a certain KnowledgeScape (cf. Heinelt et al. 2006; Matthiesen 2005). Hungary has a special characteristic in its decision-making process. This specification affects governance arrangements.

Hungary is a strongly centralized unitary country in which especially subsequent to the systemic change the medium tier governance became the weak point. Planning at regional level, elaboration of regional operational programs (ROP) met the legal and personal requirements of the EU and the Hungarian central governmental orders. The newer and newer versions of the OPs 'pursued' the continuously changing central expectations. The ROPs were made on the residual principle and their content was determined at the National Development Agency (NDA). The Government has concentrated on planning and implementing in the NDA, the ROPs were prepared in a similar linear process, even though the local organizations played a significant role in the preparative phase.

As for the content of the case-study plans, the regional operational programs were created in the framework of the Second National Development Plan (NDP), mainly based on a kind of remainder principle. This means that they did not comprise comprehensive and complex regional set of targets but rather less accented elements omitted from the sectored operational programmes, which can be considered locally, were included in these programmes. Exactly for this reason the programmes created in the seven NUTS2 regions are in many respects fairly similar, all of them characterized by thematic compromise and mixed character, since the frameworks were set by the central planner (Pálné \& Varjú (eds.) 2008).

Regarding the modes of interaction, the planning process of the ROPs (later on their Action Plans as well) and within them the SEA preparation were carried out in a sorely formalised way. The basis for this situation was formed by concrete legal regulations (the European Directive and the Hungarian Government Decree) appointing the element of governance, the actors and the competences. Based on these a hierarchical, multilevel governance model was detected which had nevertheless compulsory supplements by the elements of networking (partnership).

Although there was experience concerning the assessment of an appropriate SEA, the process was not devoid of ambiguity. On the one hand, it was not enough to take into consideration the previous experience since the volume of the SEA related to the second NDP and its operational programs 
was sorely higher, and apart that the available time for the whole planning process was short. On the other hand, the bad time management, hierarchical and centralised way of communication caused that the SEA was inadequately tailored. Although the available expert knowledge was sufficient on the side of SEA 'maker', the dominant knowledge form was the institutional knowledge on the side of central planners. Though these plans had a certain reference to territorial level, the local respect and milieu knowledge are missing. However, on the other hand, we have to emphasise that the previous experience of SEA (from the period of 2004-06) infiltrated and the structure of SEA conduction and the knowledge resulted in a positive output with regard to the SEA document.

During the SEA public participation process, the NDA provided a multi-channel option for partner's comments: partly on the website of the NDA and partly through a web interface. The planner, however, rather paid attention only to the proper "ready-made report" than to stronger cooperation with the SEA makers and the consultation partners.

If we take a look beyond the formal procedures we can see that the desirable philosophy of SEA has been injured in several aspects. First, the SEA makers were not authorised to conduct direct negotiations with the different planner units just through the NDA Department of Evaluation. This meant that the SEA maker was not the direct partner of the planning process. Its indirect manner is demonstrated by the fact that the SEA report was prepared after the public dispute on the ROP was finished and, therefore, the dispute on the report was also delayed. For the environmental assessment (including public participation) itself the time was also very short but sufficient for a proper preparation of the SEA document and assessment.

As for the media publicity of SEA preparation the picture was also depressing. Practically, we could hardly find any press release which dealt with the statements and conclusion of the SEA prepared for the NDP, and especially for the OP's. We cannot report on a more intensive media interest concerning the preparation of the ROP either, and the SEA phase completely disappeared from the eyes of the wider society. The reason is that the sophisticated content of the plans and programmes is a fairly hard task for the lay public and often even for the politicians participating in the different decision-making organs. Furthermore, the introverted attitude of the "planning experts" was explicitly apprehensible during the entire planning period. The fairly hectic and incalculable process of the bottom up and external (EU) reconciliation consumed all the energy of the planners and it was rather unimportant for them to acquire the support of the local society. The communication of the SEA phase as a last stage of the planning was accelerated by the time-pressure and was not of interest for the stakeholders as being too generalized and devoid of the local issues. However, on the other hand, we have to mention that there were several "road show" where the regional plans and later on their SEAs were presented to stakeholders.

\section{Territorial understanding}

Local understanding of sustainability was considered from the beginning of 1990s. The United Nations' Agenda 21 Programme in 1992 facilitated local actions. When analysing the Hungarian strategic documents (i.e. the mentioned and accepted version of NSRF) Péti (2012) argued that in territorial understanding popularity of sustainability is relatively high on the level of priorities, however, in most of cases the priorities repeat only general sustainability matters without any adaption to the given intervention (Péti 2012, p. 71). Analysing empirically the territorial local levels our findings can confirm the superficial state of sustainability.

The Hungarian legislative base of SEA was set up by the beginning of 2005 (2/2005 Government Order). The law concerns not only the strategic national and regional plans and programs, but also 
the local level. SEA is needed for the major structural change in urban and rural development plans, and for local sectoral (e.g., economic, waste-management etc.) plans as well.

The result of the above described empirical work shows that $3 / 4$ of the Hungarian settlements did not know anything about strategic environmental assessment. They were obtaining information on it from the empirical work. This fact pointed out that there was a defect in environmental policy integration. Although at national level the Environmental Ministry makes efforts to fulfil EPI, at lower level of territorial hierarchy the effect cannot be detected. The bottleneck of institutional infrastructure (e.g. local civil interest representation, bureaucratic and stressed "green authority") cannot ensure the base for the integration.

Table 1. The mean and the variance of the mean of the whole sample related to the answers of the questionnaire

\begin{tabular}{|l|l|l|l|l|l|l|}
\hline Settlement size & $\begin{array}{l}\text { 1. SEA can } \\
\text { contribute to } \\
\text { the conservation } \\
\text { of the value of } \\
\text { settlements. }\end{array}$ & $\begin{array}{l}\text { Variance } \\
\text { of the } \\
\text { mean. } \\
\mathbf{( \% )}\end{array}$ & $\begin{array}{l}\text { 2. The SEA } \\
\text { another } \\
\text { compulsory } \\
\text { task for local } \\
\text { governments. }\end{array}$ & $\begin{array}{l}\text { Vari- } \\
\text { ance } \\
\text { of the } \\
\text { mean. } \\
\text { (\%) }\end{array}$ & $\begin{array}{l}\text { 4. SEA is a } \\
\text { long-term } \\
\text { investment in } \\
\text { timeline for local } \\
\text { governments. }\end{array}$ & $\begin{array}{l}\text { Variance } \\
\text { of the } \\
\text { mean. } \\
\text { (\%) }\end{array}$ \\
\hline Under 500 & 3.85 & $-1.28 \%$ & 3.48 & $10.13 \%$ & 3.15 & $-6.25 \%$ \\
\hline $501-1000$ & 3.84 & $-1.54 \%$ & 4.64 & $46.84 \%$ & 3.06 & $-8.93 \%$ \\
\hline $1001-5000$ & 4.54 & $16.41 \%$ & 3.68 & $16.46 \%$ & 3.50 & $4.17 \%$ \\
\hline $5001-10000$ & 3.70 & $-5.13 \%$ & 3.08 & $-2.53 \%$ & 3.45 & $2.68 \%$ \\
\hline $10001-30000$ & 4.03 & $3.33 \%$ & 2.86 & $-9.49 \%$ & 3.71 & $10.42 \%$ \\
\hline $30001-50000$ & 4.20 & $7.69 \%$ & 3.00 & $-5.06 \%$ & 3.80 & $13.10 \%$ \\
\hline 50001 or bigger & 4.00 & $2.56 \%$ & 3.00 & $-5.06 \%$ & 3.15 & $-6.25 \%$ \\
\hline $\begin{array}{l}\text { The mean of } \\
\text { the sample }\end{array}$ & 3.90 & & 3.16 & & & 3.36 \\
\hline
\end{tabular}

Regarding the size of settlements it can be stated that bigger settlements - supposing their bigger investments - usually make major efforts to assess environmental impact. As Table 1. shows, while settlements under 1000 inhabitants see the SEA as a long term 'investment' in the future, settlements above 10000 inhabitants usually intend to do it until then.

The vast majority of the municipalities have not conducted SEA so far. Concerning the answers there are several reasons for this. Lack of information is the first one. Beside the fact that almost half of the settlements do not have any information about the SEA, most of them do not have enough financial resources for the environmental appraisal either. Half of the local governments that carried out the SEA for a certain plan used the budget of the plan as a resource for that purpose and assigned the task to the plan makers. The other half used a separate budget with a separate group for the environmental assessment.

As regards the lack of information we had to admit that the absence of knowledge led to a misunderstanding. Some of the settlements thought that the SEA was not needed because there was an EIA at the end of the process. On the other hand, a number of local governments said that SEA and Settlements' Environmental Programmes were the same thing. Certainly this is false informa- 
tion. The environmental program of local governments is prescribed by the Act of Environmental Protection (Act LIII/1995) as a mandatory task and local governments have to renew it periodically. The SEA was introduced in the governmental decree $2 / 2005$ as a mandatory task in the case of the creation of new development plans. Apart from the mentioned explanation some of the respondents thought that the SEA should have been delegated to upper decision-making levels (in the case of county, regional or national development plans).

However, we have to bear in mind that the Hungarian and the EU legislation define the need for the SEA '...in the preparation and adoption of certain plans and programs which are likely to have significant effects on the environment...' (2001/42/EC). Therefore, we cannot say that those local governments that did not prepare SEA for their development plans have broken the law, but they may declare (as some of them have done) that the development plan or its modification did not significantly affect the environment.

\section{Discussion}

Having established a position on the procedural side of the national and regional programmes, we can say that the picture is not so unambiguous despite the fact that there was earlier experience of SEA in Hungary. Analysing public debates and the method of SEA, the procedure and its outcome is debatable. Experience shows that the EPI not only depends on legislation and planning method but it also depends on the decision-making mechanism applied by the actors. Apparently this planning period (2007-2013) was the first where SEA was been made in mass volume (National Strategic Reference Framework (NSRF), its Operational Programmes and their Action Plans). Therefore, the reasons for the negative aspect included the lack of experience, the bureaucratic institutional setting, and the fact that the procedure was carried on separately, not in an iterative way, although environmental policy cogitations and plans were being worked out at the same time (concurrently or once the priorities in the plan had already been defined).

Based on the research results we can say that bureaucratic difficulties (hierarchical institutional setting, the dominance of institutional knowledge) resulted in that a 'concurrent assessment' or 'staple integration' (in the sense of Partidário \& Voogd (2004) was realised instead of the preferable 'full integration' during the SEA making. It happened that the environmental assessment was still being carried out once the planning period was finished. In this situation there is no chance to reflect on the plan in the environmental respect. In this case the SEA is made as an imperative of the legislation, but it is only an attachment of the plan.

\section{Management and Institutional infrastructure}

The term of governance has been taken up in various fields of political science deriving from the economics theory. In general the idea is applied to various changes in the process and meaning of governing. It describes the method of coordination of social actions. In a broader sense the typology of governance forms includes public and private, hierarchical, competitive and network forms of action coordination (Heinelt et al. 2006, Ostrom 2005).

Based on our mentioned (G-FORS) research Atkinson and Klausen (2011) argued that the Hungarian case was the most close to their "model 1". The most typical attributes of this governance arrangement are hierarchical and technocratic elements, low public awareness and involvement and 'tick-box' approach. In this case 'the political system and the governance arrangement were strongly 
hierarchical...so that decision-making largely reflected politico-technical criteria' (Atkinson \& Klausen 2011, p. 238).

The research results show that in the case of broad regional development programmes the intention is going forward to decision-oriented environmental assessment. The goal of the SEA conductors and planners was to include environmental interests in the strategy instead of the evaluation of impacts. The reason for that was the broad character of the plan. These development plans and programmes usually do not include specific investments; therefore it is hard to evaluate their impacts. So the aim is that during the environmental assessment process of these large-scale programmes those environmental issues should be included in these programmes.

We can draw the following consequences in relation to the research experience:

- The specific feature of Hungarian governance and the concrete circumstances of the SEA tailoring in Hungary is that a hierarchical governance mode is dominant. A hierarchical character was achieved in the relationship between central and regional decision-makers. While regional development agencies and planning working groups were formally involved in the planning process of ROPs, their content was actually defined and determined by the central planner via the use of its institutional knowledge. The union bureaucracy had a crucial role, where there was no place for bargaining and arguing. One of the reasons was that reconciliations were going on mainly between offices and authorities (e.g. regional/ national development agencies), not between policy makers (government, elected local governments).

- The experience of SEA making (in timeline) shows that there is a shift towards network governance while central stakeholders tried to achieve reconciliation horizontally, mainly among different ministry portfolios.

- In Hungary the European Union planning system is new; therefore, it is difficult to separate formal, informal and incidental elements. The 'iterative' aspects, the legislation labyrinth, the hectic connection among decision makers and planners of the planning procedure (SEA inclusive) resulted in the difficulty of identifying who had real influence on the decisions.

- Timing and time management were also problematic because there was no time for feedback and real discussion during the planning procedure.

These facts resulted in the national development programmes (e.g. National Development Policy Concept, National Territorial Development Concept, and NSRF) in which sustainability was not taken into consideration in a proper manner (see also in Péti 2012). This finding is supported by the fact that the Hungarian Government was the last of all EU Member States to adopt National Sustainable Development Strategy (NSDS) on 29.06.2007. Fundamentally, NSDS would be a proper, independent framework for tailoring SEA. Without this framework, the SEA experts made a sustainable matrix in order to assess the priorities and strategies of the plan.

The over-centralised and hierarchical governing methods do not serve the emergence of environmental aspects. Being keen on good practices in the Dutch environmental appraisal model we can find a similar and different situation. This system - partly according to its 'legislation-based situation' - has hierarchical steering elements, and it is centralized in the sense that in the Netherlands all the EIAs and a number of SEAs are submitted to an independent expert committee called the Netherlands Commission for Environmental Assessment (NCEA). It is a private foundation with its own budget funded with the governmental subsidies. Although not all the SEAs are submitted to this committee, the experience of the Dutch research results shows that most of the SEAs were submitted to the committee on a voluntary base, ensuring the expert knowledge and guarantee of the emergence 
of environmental aspects (Coenen et al. 2008). In the Dutch model the horizontal environmental (Lafferty 2004) integration was realised with its independent body in practice.

\section{Territoriality}

Péti (2012) pointed out that although in a general sense integration of sustainability considerations into regional development policy and planning was introduced, real integration lagged behind. Territorial cohesion - as an integration of sustainability consideration - did not appear in the planning documents (Péti 2012).

There is another understating of territorial sustainability which is not directly linked to territorial cohesion. It rather refers to the territorial impact of planning. Despite the fact that development policy strategies, programmes, plans - because of their genre specialties - usually do not include concrete investments related to a certain geographical area, I argue that it would be better to enforce their territorial approach. In this sense of territorial sustainability, the SEA can also be a good methodology to integrate environmental interests. As a method, in matrix-characteristic assessments, the use of ecological footprint can be a solution in order to get territorial-specific indicators.

Although in the programming procedure we cannot define the territorial manifestation of an investment, we can define materialisation accompanied by attributes of the territorial occupation process and its impact on the geographical environment.

Table 2. The impact of materialisation of the development goals on ecological environmental indicators

\begin{tabular}{|l|l|c|c|c|c|c|c|}
\hline \multicolumn{2}{|c|}{} & \multicolumn{5}{c|}{ Indicators } \\
\cline { 2 - 7 } \multicolumn{2}{|c|}{} & Cropland & Pasture & Forest & Fisheries & $\begin{array}{c}\text { Built } \\
\text { spaces }\end{array}$ & $\begin{array}{c}\text { Fossil } \\
\text { energy }\end{array}$ \\
\hline $\begin{array}{l}\text { Assessment of the } \\
\text { goals of the plan }\end{array}$ & $\begin{array}{l}\text { Sewage farm invest- } \\
\text { ments in the plan }\end{array}$ & 0 & 0 & 0 & - & + & + \\
\cline { 2 - 8 } & $\ldots$ & & & & & & \\
\cline { 2 - 8 } & $\begin{array}{l}\text { Public road network } \\
\text { development in the plan }\end{array}$ & + & 0 & + & 0 & ++ & ++ \\
\cline { 2 - 8 } & Sum & + & 0 & + & 0 & $3+$ & $3+$ \\
\hline
\end{tabular}

$0=$ no determinable impact on the change of the extent of footprint

$+\quad=$ determinable increasing impact on the change of the extent of footprint

$++=$ significant determinable increasing impact on the change of the extent of footprint

$-\quad=$ determinable decrease impact on the change of the extent of footprint

$--=$ significant determinable decrease impact on the change of the extent of footprint

Sources: Factors from Global Footprint Network, targets from the EOP and the second NDP.

In the case of general plans (such as the Operational Programmes for the planning period of 2007-2013) we can assess the environmental impacts of the development goals/priorities. Using the created matrix we can assess whether such type of investment reduces or enlarges the size of ecological productive area. We can assess which geographical indicators are affected the most and whether the materialization of the plan reduces or enlarges our ecological footprint in long term. The matrix of Table 2 can help planners and strategic environmental assessment makers in this assessment. 
Using the matrix we can argue that, for instance, an investment of a sewage farm does not reduce contamination with the waste. Its maintenance makes the use of fossil energy and the size of built spaces more extensive. But the cleaner water increases the potential of fishery, therefore, the 'occupation' of the fishery is 'negative'.

Table 3. The attributes and ideal type of SEA (in Hungary)

\begin{tabular}{|c|c|c|}
\hline Factors & Obstacles & Ideal type \\
\hline Practice of public participation & Limited opened SEA process & $\begin{array}{l}\text { Wide range, "integrated development } \\
\text { planning" }\end{array}$ \\
\hline Time management & Defect on time & Allowing time for reconciliation \\
\hline Iterativity & Follow up SEA & Iterative SEA \\
\hline Methodology & $\begin{array}{l}\text { There is not common } \\
\text { methodology }\end{array}$ & $\begin{array}{l}\text { Using widely applied methodologies and } \\
\text { independent sustainability "frameworks" }\end{array}$ \\
\hline Integration & $\begin{array}{l}\text { Concurrent assessment or } \\
\text { 'staple' integration }\end{array}$ & Full integration \\
\hline Governance & Hierarchical & Network \\
\hline Information & Incomplete & $\begin{array}{l}\text { Complete on institutional and territorial } \\
\text { level as well }\end{array}$ \\
\hline Territorial understanding & Incomplete & $\begin{array}{l}\text { Using methodology which enhance } \\
\text { the territorial understanding/integration } \\
\text { of SEA }\end{array}$ \\
\hline
\end{tabular}

As can be seen the development of public road network enlarges the cropland footprint (as well as the built spaces footprint), because new roads need new space and are the cause of a decrease in the available area of cropland but contribute to an increase in its rate per capita. The construction of roads and the more intensive use of cars result in the growth of the forest footprint because of the need for absorption of carbon dioxide. Fossil energy is needed as a fuel (used by cars on the new roads) and is needed to prepare cars as well as to maintain roads (this makes the carbon consumption increased by $45 \%$ (Wackernagel \& Rees 1996).

The use of the ecological footprint seems to be rather a popular then scientific method. However the ecological footprint assumption is based on scientific research. Using the method transparency can prevail better and the result can be more picturesque for decision-makers. The method cannot be used on its own; it can complement the decision-oriented assessment with impact-oriented assessment aspects.

Based on the experience of the first Hungarian SEAs Table 3 summarises the most important emerging factors which influenced the SEA procedure. Table 3 presents the obstacles which substantively and procedurally congested the process and also contains the ideal type of each factor which can lead to a real EPI.

Having regarded the goals above mentioned and the factors of formation and implementation of SEA the following considerations can be defined:

- The successful integration of environmental assessment - and environmental policy - into regional development decision-making process has dual conditions. On the one hand it needs 
proper expert knowledge and experience, on the other hand a helping/supporting institutional and organisational framework of the proceeding system is needed, which results in an iterative process in order to achieve the materialisation of integration.

- The institutional hierarchy and the knowledge have crucial impact on environmental policy integration. The exaggeratedly bureaucratic and hierarchical decision-making system (e.g. Hungarian public administration and planning) obstructs the effective EPI's integration into the development policy. The dominant knowledge of the bureaucratic system has institutional nature. Besides the institutional knowledge there is economic interest (a need for a cheap SEA process) which obstructs the appearance of effective expert knowledge and the efficient EPI.

- Since SEA is a new tool in Hungary, its introduction and application is a little troublesome not only at the national level but also at the county, micro regional and local levels (because of the inflexible decision-making mechanisms). Environmental Policy Integration has deficit in the planning process of settlements, micro regions and regional sectoral (e.g. waste management, water management) planning. At the higher hierarchical levels problems result from the structure of organisational/institutional specialities while on local/micro regional level the deficit is caused by the lack of information.

\section{Conclusion}

After the millennium Hungarian environmental legislation dealt with EU law-harmonization which resulted in that almost all EU requirements had been introduced by the accession. The legislation regarding the SEA was also introduced after a minor delay. Since then it has been the planners' responsibility to use the SEA in an appropriate manner and it has been the central decision-makers', authorities' and experts' task to inform the regional and local decision-makers, stakeholders and other actors about the proper manner of SEA performance.

The given national case cannot be understood of course without the concrete physical, social, cultural environment (attributes of community) and the general model of governance (Ostrom 2005). The Hungarian case study supported the opinion that general frameworks of governance were crucial factors from the aspect of the concrete action arena, they may even overwrite the special regulation and institutional environment.

Both ROP and the SEA are novelties for the Hungarian land use planning system requiring decentralized governance, partnership of non-public actors, networks for arguing and bargaining, measurement of the quality and efficiency of decisions, and respecting the normative value of sustainability. Taking into consideration the above described is crucial as the public planning for the EU planning period of 2014-20 is coming soon.

\section{Acknowledgement}

Research for this publication has been supported under OTKA - Hungarian Scientific Research Fund grant \#NK 104985 (New driving forces of spatial restructuring and regional development paths in Eastern Europe at the beginning of 21st century).

A part of work on this article was supported by the G-FORS (EU 6th FP) project. 


\section{References}

Atkinson, R., Klausen, J. E., 2011. Understanding sustainability policy: governance, knowledge and the search for integration. Journal of Environmental Policy \& Planning, vol. 13, no. 3, pp. 231-251.

Coenen F., Denters, B., Klok, P.J. \& Kotzebue, J., 2008. G-fors Dutch national report Working Paper (University of Twente), http://www.hannover.de/europa/data/download/Projekte/GFORS/Netherland.pdf [14 August 2013].

Czira T., Jusztin V. \& Sovago K., 2004. A társadalmi-gazdasági és környezeti hatásértékelés szerepe a területi tervezésben. Területi statisztika, vol. 44, no. 1, pp. 3-20.

Dąbrowski, M., 2008. Structural funds as a driver for institutional change in Poland. Europe-Asia Studies, vol. 60, no. 2, pp. 227-248.

Degórski, M., 2010: Socio-economic responses to the environment and ecosystem services in regional development. Geographia Polonica, vol. 83, no. 2, pp. 83-95.

Florjańczyk, Z., Janc, K., Czapiewski, K. Ł., 2012. The importance and diffusion of knowledge in the agricultural sector: the Polish experiences. Geographia Polonica, vol. 85, no. 1, pp. 45-56.

Feldmann, L. \& Vanderhaegen, M., 2001. The EU1s SEA directive: status and links to integration and sustainable development. Environmental Impact Assessment Review, vol. 23, no. 2, pp. 203-222.

Heinelt, H., Held G., Kopp-Malek, T., Matthiesen, U. Reisinger, E. \& Zimmermann, K., 2006. Governance for Sustainability. Conceptual Framework for the G-FORS project. Working Paper (unpubl.)[typescript].

Lafferty, W.M. \& Hovden, E., 2003. Environmental policy integration: Towards an analytical framework. Environmental Politics, vol. 12, no. 3, Autumn, pp. 1-22.

Lafferty, W.M., 2004. From environmental protection to sustainable development: the challenge of decoupling through sectoral integration. [in:] LAFFERTY, W.M (ed) Governance for Sustainable Development. The Challenge of Adapting Form to Function, Cheltenhan, Edward Elgar, pp. 191-220.

Lenschow, A., 1997. Variation in EC environmental policy integration: agency push within complex institutional structures. Journal of European Public Policy, vol. 4, no. 1, pp. 109-127.

Lenschow, A., 1999. The greening of the EU: The Common Agriculture Policy and Structural Funds. Environment and Planning C: Government and Policy, vol. 17, no. pp. 91-108.

Matthiesen, U., 2005. KnowledgeScapes. Pleading for a knowledge turn in a socio-spatial research. Working Paper (Erkner, IRS) http://www.irs-net.de/download/KnowledgeScapes.pdf [14 August 2013]

Ostrom, E., 2005. Understanding Institutional Diversity, Princeton and Oxford, Princeton University Press.

Pálné Kovács I., Paraskevopoulos, C. J. \& Horvath GY., 2004. Institutional “legacies” and the shaping of regional governance in Hungary. Regional \& Federal Studies. vol. 14, no. 3, pp. 430-460.

Pálné Kovács I. \& Varjú V. (eds.) 2008. G-FORS Case Studies on SEA and ETS in Hungary (Pécs, CRS of HAS) Wroking Paper, http://www.hannover.de/europa/data/download/Projekte/GFORS/ Hungarian.pdf, [14 August 2013].

Partidário, M. \& Voogd, H. 2004. An Endeavour at Integration in Environmental Analysis and Planning. [in:] MILLER, M. \& DE ROO, G. (eds.) Integrating City Planning and Environmental Improvement. Practicable Strategies for Sustainable Urban Development (Aldershot, Ashgate) pp. 285-294. 
Péti M., 2012. A territorial understanding of sustainability in public development. Environmental Impact Assessment Review, vol. 32, no. 1, pp. 61-73.

Sadler, B., 1996. Environmental assessment in a changing world: evaluating practice to improve performance. Minister of Supply and Services Canada, Ottawa.

Szilvácsku Zs., 2003. Stratégiai környezeti vizsgálatok gyakorlata az Európai Unióban. Budapest, Vitaregnat Bt.

Theophilou, V., Bond, A., Cashmore, M., 2010. Application of the SEA Directive to EU structural funds: Perspectives on effectiveness Environmental Impact Assessment Review, vol. 30, no. 1, pp. 136-144.

Therivel, R., 2004. Strategic Environmental Assessment in Action. London, Eartscan

Therivel, R., Christian, G., Craig, C., Grinham, R. \& Mackins, D., Smith, J., Sneller, T., Turner, R., Dee, W. \& Yamane, M., 2009. Sustainability-focused impact assessment: English experiences. Impact Assessment and Project Appraisal, vol. 27, no. 2, June, pp. 155-168.

Varjú V., 2008. Environmental Respects of Regional Planning: Strategic Environmental Assessment (SEA) in Hungary. [in:] Wawge, R.S. (ed): Strategic Environmental Assessment. Perspectives, applications and practices. The Icfai University Press, Hyderabad, India. pp. 47-58.

Wackernagel, M. \& Rees, W., 1996. Our ecological footprint. Reducing human impact on the Earth. Canada, New Society Publishers.

Wood, C., (ed.) 2005. Strategic Environmental Assessment and Land Use Planning: An International Evaluation. London, Earthscan Publications. 